Ingo Strauch

\title{
Looking into water-pots and over a Buddhist scribe's shoulder - On the deposition and the use of manuscripts in early Buddhism
}

\begin{abstract}
The article investigates the modes of use of early Buddhist manuscripts in a monastic environment. Based mainly on the evidence of archaeological and manuscript data from North-West India (Gandhāra) it discusses the circumstances under which manuscripts were produced, used and deposited by early Buddhist communities. In this regard, the article critically evaluates the hypothesis of a "ritual burial" of manuscripts in the stūpas of "Greater Gandhāra". A special paragraph is devoted to the unique birch-bark manuscript of a portion of the Prātimokșasūtra from the Bajaur Collection of Kharoșthī manuscripts. The two sides of the birch-bark contain two different versions of the initial part of the naihsārrgika pātayantika chapter of the Prātimokșasūtra. A comparison with known canonical texts shows that these two versions can be associated with two different Prātimokṣasūtra traditions. They are, however, not identical with any of the known versions which are usually attributed to specific Buddhist schools (nikāyas). It therefore seems justified to characterise them as proto-canonical or/ and local/regional versions of this fundamental text. The analysis of the language and the contents of the two versions allows cautious conclusions about certain aspects of the role of writing and of manuscripts in the emergence of authoritative canonical texts within Buddhist textual traditions.
\end{abstract}

DOI 10.1515/asia-2014-0063

\section{Introduction}

Buddhists were among the first religious communities in India that took the momentous decision to write down their texts. As far as we know, this process started in the first century BCE. According to the material evidence, the North-West of the Indian subcontinent ("Greater Gandhāra") was one of the first regions to start this paradigmatic shift. Within a comparatively short time, Buddhism became a true

Ingo Strauch: Section de langues et civilisations slaves et de l'Asie du Sud, Université de Lausanne, Anthropole, 1015 Lausanne-Dorigny, Switzerland. E-mail: ingo.strauch@unil.ch 
writing culture engaged in the production, distribution and even veneration of written texts in the shape of manuscripts. This process was preceded by several centuries of oral transmission which had given the texts a specific shape and had also developed a complex system of text contraction and expansion. In many cases, texts were transmitted not in their full length but in a condensed form which could be enlarged according to demands of the situation. Conversely, long texts could be contracted. Fixing such fluid textual bodies into the language of writing presupposed a series of changes and editorial decisions which heavily influenced the actual shape of a given text in its written form.

At the same time, it can be suggested that the process of writing down a text or text corpus was not an abrupt one. It rather took place as a series of consecutive events and was accompanied by a considerable period of simultaneous oral transmission. That these two strands of textual transmission influenced each other is probable, although the mechanisms of these complex processes are largely unknown. Generally we have access only to their results as manifested in the extant canons of different Buddhist schools (nikāya). ${ }^{1}$ It is therefore generally assumed that these specific text shapes emerged already during the period of oral transmission within one school and can be regarded as characteristic for this school.

But is this really the case? Or is the distinctive shape of a text rather the accidental result of a process which was dependent on the specific time and region or even locality when and where this text was transferred from its oral form into a fixed written shape? It is obvious that this question directly touches the problem what was the basis for the self-identity of Buddhist schools in the centuries that preceded those when they actually made use of a written canon. At the same time our capacity to answer this question is largely dependent on our knowledge of the agents in this process and on the mode of use of manuscripts in a specific institutional environment.

Recently, Gregory Schopen published an article in the volume Écrire et transmettre en Inde classique (2009), in which he addresses three crucial questions which can be subsumed as:

1. Where were Buddhist manuscripts produced?

2. Who produced and used them?

3. How were they used?

1 For the complexity of methodological problems connected with the comparative analysis of these canonical versions see Schopen's discussion of several Vinaya passages (Schopen 1985: 14-22 = Schopen 1997: 25-29). 
Schopen discussed these questions mainly on the basis of the manuscript material from Gilgit - certainly one of the most eminent find-spots of Buddhist manuscripts yielding material from about the sixth to eighth centuries CE.

Based on the archaeological evidence, Gérard Fussman had rejected the long prevailing assumption that the building in which the Gilgit manuscripts were discovered was a stūpa. According to him, the Gilgit structure "était à la fois le logis et la chapelle d'une lignée d'ācārya dont certains exécutèrent des rites de protection demandés par des notables de Gilgit." With regard to the assumed use of these manuscripts, Fussman concludes: "Les manuscripts de Gilgit sont les ouvrages dont se servaient les ācārya dans leur pratique monastique ordinaire, auxquels s'ajoutent des livres copies et dons pieux et cérémoniellement remis au monastère."2

Schopen critically evaluates this hypothesis and argues, that the building where the manuscripts were kept, might have been "a kind of sacred workshop, a combination of genizah and scriptorium, where old, unusable, or returned manuscripts were kept, along with some master-copies, and where new manuscripts were manufactured and were for sale". ${ }^{3}$ With regard to the persons who worked in this workshop, who sold and who used the manuscripts, Schopen concludes, "that more laymen than monks were involved in the production and use of these manuscripts". 4

Concerning the mode of the use of manuscripts, Schopen stresses the prominence of texts relating to "healing, apotropaic or death rituals". The manuscripts were obviously used in this context, quite frequently "in the form of a manuscript [...] as an object of worship". The question, how "such ritual use or purpose might impact on textual quality or linguistic shape", ${ }^{5}$ Schopen approaches by investigating the different versions of the Bhaișajyaguru-Sūtra that are found among the Gilgit material.

In the very beginning of his article Schopen defines the more general, overarching motif of his study, namely: "trying to understand how Indian religious texts were shaped, or the forms they might have circulated in." According to Schopen, early Mahāyāna literature has a special importance for this purpose, based on the fact that "(m)any of these sūtras - perhaps most - were, for example, translated into Chinese and Tibetan, sometimes very early into Chinese, and many of these early translations can be dated with some certainty. For some Mahāyāna sūtras, moreover, we have what are, by Indian standards, some very early Sanskrit

2 Fussman 2004: 134.

3 Schopen 2009: 203.

4 Schopen 2009: 203.

5 Schopen 2009: 204. 
manuscript materials - the very thing so often missing for other Indian texts". However, as Schopen rightly points out, "most of the 'early' manuscript material is later, becoming relatively abundant only for the $5^{\text {th }}$ to the $7^{\text {th }}$ century" ${ }^{6}$

But what is true for the early Mahāyāna sūtra tradition, is still more valid for texts which are represented in the preserved parts of the literary production of ancient Gandhāra. ${ }^{7}$ The last decades witnessed the discovery of an enormous number of manuscripts produced in the extreme north-west of the Indian subcontinent. The oldest of these manuscripts are on birch-bark and contain texts which are written in the Kharoșţhī script and composed in the Gāndhārī language. Both script and language are characteristic for the cultural area, for which Richard Salomon shaped the term "Greater Gandhāra", and were used up to the late third - early fourth centuries CE. ${ }^{8}$ As radiocarbon dating shows, these birch-bark manuscripts are the oldest preserved Buddhist and even Indian manuscripts. The earliest of them can be dated to the first or even the second century BCE, ${ }^{9}$ i.e., the period in which we assume that Buddhist texts were first written down. The majority of the Kharoșthī manuscripts dates to a slightly later period ranging from the first to third centuries CE. But even they are much earlier than the bulk of the so far known Buddhist manuscripts. Consequently, they provide access to a crucial period of Buddhist religious and literary history, a period, which is otherwise nearly inaccessible to us. For the first time we are now in a position to contrast the evidence of the Chinese translations with an independent Indian tradition, which is contemporary to and in part even older than that of the Chinese.

It seems therefore worthwhile to take up the important issues discussed by Schopen on the basis of this new evidence. For brevity's sake, I will limit the discussion here mainly to the material of one of these new manuscript collections, the Bajaur Collection, which has been studied in Berlin (and now in Lausanne and Munich) since 2005. ${ }^{10}$

6 Schopen 2009: 204.

7 For a survey of Gandhāran literature, see now Falk and Strauch 2014.

8 For the late phase of the use of Kharoșthī, see Salomon 2008 and Strauch 2011.

9 The earliest dated Kharoșțī manuscript is the Avadāna fragment of the "Split Collection". Its radio-carbon dating yielded a calibrated date of " $B C$ 184-46' with a probability of $95.4 \%$ ", a date which Falk considers, however, as "difficult to digest” (Falk 2011: 19).

10 From 2005-2012 the Bajaur Collection was studied in the framework of a DFG project at Freie Universität Berlin. Since 2012 its edition is part of the project "Buddhist Manuscripts from Gandhara" at the Bavarian Academy of Sciences, Munich, in collaboration with the Chair of Buddhist Studies at the University of Lausanne. 


\section{The Bajaur Collection of Kharoṣthī manuscripts and the theory of the "ritual burial of Buddhist manuscripts"}

The Bajaur Collection of Kharoșțī manuscripts consists of fragments of nineteen birch-bark manuscripts written by different scribes and comprising texts from different genres of Buddhist literature. ${ }^{11}$ It was discovered more than 15 years ago in the Bajaur disctrict of the North-Western Frontier Province (now: Khyber Pakhtunkhwa) of Pakistan. Like many of these new discoveries, it was not found in the course of regular excavations. However, the information regarding the location, circumstances and context of the discovery is unusually detailed and could be partially confirmed by independent sources. Nevertheless, there remains a certain degree of doubt. As communicated by the finders of the hoard, the birch-bark manuscripts were found in the ruins of a Buddhist monastery in a stone chamber measuring ca. $0.5 \mathrm{~m}$ in diameter. This chamber was situated in one of the monastery's cells. ${ }^{12}$

As I noted in my first publication on the Bajaur Collection (2007/8), this feature clearly distinguishes the Bajaur collection "from the British Library or Senior collections, which both were found inside earthen pots. It is probable that these pots were deposited inside a stūpa, from where they were taken by the illegal diggers. Either they were no longer in a usable and intact condition as R. Salomon suggested with regard to the British Library collection ${ }^{13}$ or they were intentionally written in order to be buried inside a stūpa as one might suggest in the case of the Senior collection which was interred as an intact and cohesive collection. ${ }^{14}$ The deposition inside a stone chamber, however, is a new feature. Obviously, the Bajaur manuscripts were not ritually buried but stored in a room within the precincts of a Buddhist monastery". ${ }^{15}$ At the same time, I proposed to characterise this room or rather the stone-box as "rather a (part of a) monastic library than an intentional collection of texts. Since, practically, all of the manuscripts are more or less fragmentary, the comparison to a Jewish genizah brought forward by Salomon with regard to the British Library fragments (1999: 81-84) could be equally valid for the new Bajaur collection. It seems that old and wornout manuscripts

11 For more detailed information regarding the Bajaur Collection cf. Strauch 2007/8 and Strauch 2008.

12 See Strauch 2007/8: 6-7.

13 Salomon 1999: 69-71.

14 Salomon 2003: 78-79.

15 Strauch 2007/8: 6f. 
were sorted out and stored in one place, outside the regular library (for which a stone casket would be rather uncomfortable) but still in reach of the monks in case of urgent need. Probably, not all of the texts were partially destroyed. Some of them might have been sorted out for other reasons". ${ }^{16}$

This interpretation - based, I have to admit, on secondary evidence of somewhat disputable reliability - was criticised by Richard Salomon. In his paper "Why Did the Gandhāran Buddhists Bury Their Manuscripts", he supposes instead that "the Bajaur scrolls, like the other Gandhāran manuscripts, were ritually buried in the relic chamber of a stūpa, either loose, or, as I suspect is more likely, in a clay pot or other container which has not been preserved, perhaps because it was broken in the course of an illicit excavation". ${ }^{17}$ This interpretation was recently challenged by G. Fussman who suggested instead to regard the stone-chamber as "un espace aménagé au-dessus du sol dans une cellule, autrement dit un coffre en pierre de $50 \mathrm{~cm}$ de côté" and to consider the possibility that this stone box was part of a monastic library. ${ }^{18}$

Due to the lack of more reliable information it is hard to decide on an unanimous solution. It seems to me, however, that the fact that the other Gandhāran manuscripts were "ritually buried in the relic chamber of a stūpa" is not as certain as Salomon's statement suggests. We have to bear in mind that in the majority of cases we have not the slightest idea about the circumstances of the manuscripts' discovery.

Salomon's theory on a ritual burial of Gandhāran manuscripts is mainly based on two facts:

1. In some cases remains of Kharoșthī manuscripts were found inside earthen pots. There is evidence that earthen pots were also used as relic containers or funereal urns. Consequently, it is possible to assume a functional parallelism between both types of filled vessels.

2. In many cases manuscript remains were discovered in the interior of stūpas - either among the contents of reliquaries or in relic chambers.

Salomon supports both these points with several pieces of data. ${ }^{19}$ But does the evidence he cites exclude alternative explanations? Manuscript fragments have indeed been found inside earthen pots. ${ }^{20}$ But to evaluate the data it is necessary

16 Strauch 2007/8: 66.

17 Salomon 2009: 29.

18 Fussman 2012: 198.

19 Salomon 1999: 59-68, 77-81.

20 Although the Khotan Dharmapada is sometimes said to have been stored in a ceramic vessel, its original find-spot and its connection to the ceramic bowl in the vicinity of which it was reported to have been found are unclear (Salomon 1999: 58f.). 
to take a closer look at the evidence and its bearing on the hypothesis of a "ritual burial of manuscripts". Two questions are crucial:

1. What is the specific character of the vessel? Is it a water-pot or a reliquary or a water pot rededicated as a reliquary?

2. What is the character of the manuscript remains discovered under these circumstances?

I will try to answer these questions on the basis of the available evidence for some of the examples quoted by Salomon.

The birch-bark manuscripts of the British Library Collection were sold on the art market in a pot which was dedicated to the Dharmaguptaka school. ${ }^{21}$ Its shape suggests that the vessel was originally a water-pot, rededicated for a secondary use as a depository for manuscripts. The inscription on the pot does not refer to this secondary use; nor does it indicate any association with a burial or relic context. It is, however, quite certain that the manuscripts were originally stored in this pot.

In the case of the Hadda fragments discovered by Masson and Barthoux at various stūpa sites we are generally quite weakly informed about the archaeological contexts and the character of these manuscript remains. ${ }^{22}$ However, what Masson and Barthoux usually describe, suggests that most of their manuscript finds represented rather small pieces of birch-bark of a distinctively different character than our manuscript collections. In illustration I cite Masson's observations on the relics of the Haḍda stūpas:

The relics generally found in the topes of Afghanistan are ... enclosed in caskets or vases of copper, brass, and steatite. [...] In the larger vases is usually discovered a portion of fine pulverised earth or of ashes, amongst which have been placed burnt pearls, beads, rings, seals, and other trinkets [...] In some examples the deposits have been accompanied by twists of tuz-leaves inscribed internally with characters. These may have contained the precise information we seek. The only other probable conjecture as to these twists, is that they contain mantras or charms. ${ }^{23}$

Masson's subsequent description makes clear that the script he saw was Kharoșţī. Although Masson was not able to give any further information - also

21 The pot bears the inscription: saghami caüdiśami dhamaüteaṇa [p]arig[r]ahami "[Given] to the universal community, in the possession of the Dharmaguptakas." (= Pot D of the British Library Collection, Salomon 1999: 214 = CKI 372). The siglum CKI refers here and further on to the Catalogue of Kharoșthī Inscriptions compiled by Stefan Baums and Andrew Glass (www.gandhari.org). For further bibliographical information regarding the cited texts, cf. there. 22 The relevant material is collected by Salomon (1999: 77-81).

23 Wilson 1841: 59-60. 
due to the very deteriorated condition of the manuscripts - his report supplies three important pieces of information: First, the majority of reliquaries was made of material other than ceramic. Second, the manuscripts remains were not the only content of the reliquary, but they accompanied the relic. Third, his assumption that the "twists" contained mantras or charms, implies that the manuscript remains were rather small and would hardly represent longer Buddhist texts.

Masson mentions only one case, where such a manuscript fragment was found inside a reliquary made from earthenware. In "tope 13" he "fell upon a small earthen jar, enclosing a stone wrapped in tuz-leaves [...] encompassed with a Bactro-Pali (i.e. Kharoșțī, I.S.) inscription, written with a pen, but very carelessly". ${ }^{24}$ As Salomon rightly remarks, the inscription is not on the "tuz leaves", i.e. the birch-bark, but on the small jar itself. It is the so-called "Hidda inscription of the year 28" published by Konow. ${ }^{25}$ This Haḍda pot is one of the few examples of inscribed reliquaries made from earthenware. ${ }^{26}$ Its inscription and its shape are completely different from what we know of the inscribed water-pots. ${ }^{27}$ Both inscription and shape make clear that the vessel was intentionally produced as a reliquary.

More ceramic pots from Haḍ̣a with manuscript fragments were described by Barthoux, whose description almost literally matches that of Masson. ${ }^{28}$ Unfortunately, Barthoux' report cannot help to establish the type of these pots. However, as observed by Tarzi during his excavations in Tepe Shotor in the Hadda area, the use of water-pots as relic containers or funeral vessels is more an exception than the rule. ${ }^{29}$

24 Wilson 1841: 111.

25 Konow 1929: 157-158, Konow 1935/3 = CKI 155.

26 For another earthenware reliquary dated Year 44 (of the Kaniṣka era) see Strauch 2007: 79-83 (CKI 511). Despite the somewhat unusual shape of the vessel and its non-standard inscription I do not share the doubts expressed by Salomon (2012: 171, fn. 15). It is, however, possible that the pot was not intentionally produced as a reliquary, but rededicated. Its inscription is incised on the burnt surface.

27 The archaeological and inscriptional evidence on earthenware reliquaries has been briefly discussed by Strauch (2007: 81f.)

28 Cf. Barthoux 1933: 60: "le contenu des poteries n'était plus qu'une sorte de terre à laquelle étaient mélangés des débris de manuscrits (papier d'écorce) [...] ou des monnaies.”

29 Cf. Tarzi 2005: 224: "Dans de rares cas, et à défaut d'urne funéraire, l'une des jarres globulaires ou le chaudron du moine lui servait d'ostothèque pour contenir les restes de son corps incinéré." The ordinary funeral pots of Tepe Shotor are described by Tarzi: "Toutefois ces urnes ne portent pas d'inscription. Dans la plupart des cas, ce sont de simples pots contenant les os incinérés des moines, posés au pied des murs extérieurs des monastères” (2005: 224). They are obviously different from the numerous globular water jars - several of them inscribed - which were also excavated at this site. 
Another factor has to be considered: Although many of the fragments from Haḍda come from stūpas, more precisely from the interior of reliquaries (a fact which is also due to the limited extent of the excavations carried out, which were mainly concentrated on the stūpa sites), there are significant deviations from this pattern: Thus Barthoux mentions several cases in which manuscript remains were discovered in the debris of chambers. ${ }^{30}$

One of the few cases where we are quite well informed about the archaeological context of a manuscript find comes from the Jauliāñ monastery at Taxila. In cell 29 the excavators discovered "fragments of a Sanskrit manuscript [...] in an earthenware vessel [...]. The manuscript, which was written on birch-bark, had been half incinerated when the monastery was burnt down [...]". ${ }^{31}$ According to its palaeography, the manuscript belongs to the fifth c. CE and seems to contain "a narrative and not a didactic composition, and to have embodied a large number of verses". ${ }^{32}$ Remarkably, the pot containing the manuscript was not found in a stūpa, but in a cell. ${ }^{33}$

As archaeological parallels for the "burial of books in later Buddhistic practice" Salomon also referred to the "birch bark manuscripts dating from about the fifth and sixth centuries A.D. [...] found inside painted clay vases buried in the stūpas at Merv and Bairam Ali in Turkmenistan". ${ }^{34}$ According to the description given by Staviskiy, the Merv vase containing the manuscripts was found within the precincts of the stūpa complex Gyaur Kala, but not inside the stūpa. ${ }^{35}$ As the excavators report, it was deposited in the foundation structures of the stūpa. The painting on the nearly $50 \mathrm{~cm}$ high, richly decorated vase depicts "the life and death of a certain high-ranked noble man. Neither by its shape nor by the contents of the painting the vase is connected to Buddhism". ${ }^{36}$ Based on this description, the function of the vase as a reliquary is at least doubtful.

30 Barthoux 1933: 61, cf. Salomon 1999: 63.

31 Marshall 1951: 387. See also Marshall 1921: 20. The fragmentary manuscript is described and partially edited by Chanda 1921: 66-75. See also plate xxix for images of some of the altogether 52 fragments.

32 Marshall 1951: 387.

33 Cf. also Salomon 1999: 77.

34 Salomon 1999: 84.

35 Staviskiy 1998: 98-99.

36 Translated from the Russian of Staviskiy 1998: 100. For an image of the vase see fig. 74 on p. 99. According to Vorob'eva-Desyatovskaya (1983: 69) the excavators assumed that the vase was deposited "below the structures of the stūpa during the restoration works in the $5^{\text {th }}-6^{\text {th }}$ cc.". This information is confirmed by Koshelenko (1966) who provides a detailed analysis of the vase's decoration including high-quality colour images. 
The archaeological context of the Bairam Ali manuscripts, which contain texts of the Vinaya and avadāna/jātaka genres, is equally uncertain. ${ }^{37}$ The complex "Gyaur Kala II” near Merv, from where they were allegedly procured, was completely destroyed by the local population before excavations could be carried out. Vorob'eva-Desyatovskaya describes the discovery of the Bairam Ali manuscript as follows:

The discovery was in fact incidental: while levelling the field, the driver of a bulldozer demolished a small hill. Among the clumps of earth he discovered an earthenware pot that was broken to smithereens. On the ground were scattered ancient coins, a certain statue and a bundle of birch-bark leafs sticking together and bearing unintelligible signs. ${ }^{38}$

Even the character of this complex is not clear, although it is assumed that it was a stūpa, which was perhaps part of a larger complex. ${ }^{39}$ Due to these circumstances, neither of the cases can serve as archaeological parallels for the practice of the burial of manuscripts in Buddhist stūpas.

Subsuming this evidence, it seems that there is not a single archaeologically confirmed instance of a water-pot (or vase) deposited in a stūpa as a reused reliquary containing manuscript remains. ${ }^{40}$

The fact, however, that manuscript remains were part of the contents of relic containers cannot be denied. But as far as the fragmentary reports by Masson and Barthoux allow us to judge, almost all of these manuscript remains, which were found in Haḍda, Jalalabad and the adjacent areas, seem to belong to a common type. Usually they are described as tiny fragments similar to apotropaic amulets. In many cases these manuscripts might have contained a text of the Pratityasamutpāda family ${ }^{41}$ or of the group of apotropaic, dhāraṇi like texts. In accordance

37 See for Vorob'eva-Desyatovskaya's edition of this manuscript Bongard-Levin et al. 2004: 273-336.

38 Translated from the Russian of Vorob'eva-Desyatovskaya 2004: 273. It should be noted that this description differs remarkably from that given by the same author in 1983: "The manuscript in the shape of a bundle of leafs sticking together was located in an earthenware vessel that was immured in a Buddhist stūpa" (translated from Vorob’eva-Desyatovskaya 1983: 69). Litvinskiy even speaks about excavations carried out at this site, evidently ignoring or hiding the fact that the discovery of this manuscript was an incidental event (Litvinskiy 1992: 436 = Litvinsky 1999: 13).

39 Staviskiy 1998: 100-103.

40 It should also be kept in mind that the majority of Buddhist manuscripts discovered in Xinjiang were found in the cells of Buddhist monastic institutions (cf. for the Turfan oasis Sander 1968: 8-21).

41 For such a manuscript cf. the birch-bark with the Brāhmī text of a Pratìtyasamutpādasūtra described by Hartmann (2009: 101-103). According to reports, it was found by local workers "in 
with this character of text, remains of such manuscripts were found in different contexts. Some of them were found inside a stūpa as part of the contents of a relic container. Others were deposited in the hands of Buddha statues, in holes in the walls, etc. ${ }^{42}$ This type of manuscript deposit - which were definitely perceived as a kind of relic - should be strictly distinguished from cases where an entire manuscript or even a manuscript collection is found. Here our evidence is far from satisfying.

The same situation was observed by David Drewes, who discussed the deposition of manuscripts and books in stūpas on the basis of a comprehensive survey of archaeological data from early Buddhist sites in South Asia. ${ }^{43}$ Subsuming the available evidence he says: “[...] actual 'books’ were deposited in stūpas only very rarely. When texts were put in stūpas they were usually very short sūtras or quotations from sūtras pressed into or inscribed on clay or metal."44

Taking up our two initial questions, it can be subsumed:

There are numerous cases of vessels containing manuscripts. If the character of a vessel can be clearly determined as an (original or rededicated) reliquary, the manuscript remains are usually very small and contain texts with a specific ritual function (Prātītyasamutpāda, mantra, etc.). If larger manuscripts or entire manuscript collections are concerned, they can be stored in water-pots or other types of vessels (e.g. Merv). There is no unanimous evidence that forces us to place these vessels in the interior of a stūpa. Their function as reliquaries cannot be determined on the basis of the available evidence.

However, there is one collection of Gandhāran manuscripts which clearly supports Salomon's interpretation: The Senior collection was obviously deposited in an earthen pot bearing an inscription in a "formulaic pattern that is regularly associated with the relic deposits or stūpa foundations". ${ }^{45}$ The inscription on the lid of the pot even specifies the place of its deposition: thubami "in the stüpa". ${ }^{46}$ Usually such vessels contain relics. If the manuscripts are the original contents of the pot - and there is good reason to believe this ${ }^{47}$ - the Senior Collec-

the niche of the smaller of the two Buddhas at Bamiyan” (Hartmann 2009: 101). For this class of manuscripts see also Salomon 1999: 85-86.

42 Cf. Barthoux 1933: 61, Salomon 1999: 64.

43 Drewes 2007: 126-133.

44 Drewes 2007: 133.

45 Salomon 2009: 26.

46 CKI 245, Salomon 2003: 76.

47 In his review of Glass 2007, Fussman expresses serious doubts with regard to this fact: "Il n'est pas exclu que les rouleaux à l'origine ne se trouvaient pas dans le vase supposé les avoir contenus et qu'ils y aient été placés soit après leur découverte, pour les transporter, soit au moment de la vente, pour en augmenter le prix parce que le premier lot de manuscrits parvenu à 
tion would indeed represent a case of a collection of Gandhāran manuscripts perceived as Buddhist relics, which were meant for being deposited inside a stūpa.

But is it possible to generalise this evidence? The Senior Collection is exceptional. It is written by a single scribe and seems to represent a collection of texts which was done according to a previously established plan, or - as Mark Allon says - a "commissioned collection". ${ }^{48}$ It is possible that this collection was made for being deposited inside a stūpa and for consecrating it.

If we look again at the Bajaur Collection, it is much more related to the British Library Collection. Both are heterogeneous compilations of texts written by numerous scribes and containing different genres of Buddhist literature. The state of the manuscripts' preservation is different - ranging from almost completely preserved scrolls up to manuscripts with large portions missing. With regard to these features, the characterisation brought forward by Salomon for the British Library Collection (genizah) or even by Schopen for the Gilgit manuscripts - genizah cum scriptorium - might work quite well. In both cases the manuscripts were seemingly deposited in a way that excluded them from direct access. It is therefore possible that these manuscripts were not in actual use, but sorted out for different reasons. The assumption that the containers of both collections were "ritually buried" cannot be disproved, but there is also little evidence to verify it. Other scenarios seem to be equally plausible.

During excavations, water-pots were mostly discovered in the context of monastic cells or courtyards. ${ }^{49}$ As mentioned above, the Brāhmī manuscript from the Jauliāñ monastery was found in a cell. Thus in the case of Gandhāran manuscripts stored in water-pots one might also argue from a more practical perspective: Putting manuscripts into such a type of vessel is a quite effective protection for any kind of external damage - especially against insects. And such a more prosaic approach would also pave the way for Schopen's idea of a scriptorium. Based on this interpretation, both the British Library and the Bajaur Collection would represent compilations of manuscripts coming from the interior of the scriptorium of a Buddhist monastery, kept within the precincts of the monastery in a protective depository. This is one possibility, but by far not an exclusive one.

Although our texts are usually not very informative about this side of the monastic life, there is one passage from the Mūlasarvāstivāda Vinaya which

la British Library se trouvait dans un vase semblable dont l'inscription ajoutait à leur valeur" (2012: 193). I do not share these doubts nor his reservations regarding the assumed function of the pot as relic container (cf. Fussman 2012: 194).

48 Allon 2007: 4.

49 See Tarzi 2005 and Marshall 1951: 380. A useful survey on the percentage of water-pots in excavated sites in Gandhāra is given by Tarzi 2005: 219-222. 
seems to shed at least some light on this issue. In his paper on "Deaths, Funerals, and the Division of Property in a Monastic Code" Schopen cites a passage from the Civaravastu as preserved among the Gilgit manuscripts. The passage describes the division of a householder's property who died before being ordained and - as he was childless - left all his estate to the Buddhist community after having sent a written will to the Jetavana garden at Śrāvastī. ${ }^{50}$ The Buddha then prescribes how the order should handle different types of property. With regard to books (pustaka), he says: ${ }^{51}$

pustakānām buddhavacanapustakā avibhājyā cāturdiśāya bhikṣusaṃghāya (sā)dhāraṇā koșțhikāyāṃ prakșeptavyāḥ bahiḥśāstrapustakāḥ bhikșubhir vikrīya bhājayitavyāḥ ${ }^{52}$

Of books, books of the word of the Buddha are not to be distributed but to be deposited in the storehouse as property in common for the Community of Monks from the Four Directions. The books containing the treatises of non-Buddhists are to be sold, and the sum received is to be distributed among the monks. ${ }^{53}$

As Schopen has shown elsewhere, ${ }^{54}$ Dutt's erroneous reading of the text (dhäranakoșţikāyām) created a ghost-word that was also incorporated in Edgerton's Buddhist Hybrid Sanskrit Dictionary. As the subsequent passage of the Civaravastu shows, sädhāraṇa- and koșthikē - have to be perceived as two separate words. The term koșthikā is rendered in the Tibetan parallel of this passage and elsewhere in the Vinaya as mdzod "store-house, magazine, depository, strong-box". 55

Manuscripts were not the only objects deposited in a koșthikā. A passage from the Vinayavibhanga tells us, that also money given to the order as perpetuity (akșayanīvī) was kept in a mdzod/koșțikā. ${ }^{56}$ And our Cìvaravastu passage continues: ${ }^{57}$

50 Schopen 1995: 498-500 = 2004: 117-119.

51 Fol. 174b, 1.4, read from the facsimile in Raghu Vira and Lokesh Chandra 1995, plate 861.

52 Dutt's edition reads this passage: pustakānām buddhavacanapustakā avibhajya cāturdiśāya bhikṣusaṃghāya dhāraṇakoṣthikāyāṃ prakṣeptavyāh / bahihśāstrapustakā bhikṣubhir vikrīya bhājayitavyāh (Dutt 1942: 143, lines 5-7). I express my gratitude to Lore Sander (Berlin) for discussing the manuscript readings during a meeting in May 2014.

53 Translation by Schopen 1995: 500 = 2004: 119, emphasis added.

54 Schopen 1994: 530-531 = 2004: 50-51.

55 Jäschke 1881, s.v.

56 Schopen 1994: $529=$ 2004: 48 .

57 Fol. 174b, lines 4-5, read from the facsimile in Raghu Vira and Lokesh Chandra 1995, plate 861. 
patralekhyam yac chīghram śakyate ${ }^{*}$ sādhayitum ${ }^{58}$ tasya dravyavibhāga tad bhikșubhir bhājayitavyam na śakyate tac cāturdiśāya bhikṣusaṃghāya sādhāraṇaṃ koșțhikāyāṃ prakșeptavyah (read: -vyam) ${ }^{59}$

Any written lien that can be quickly realized - the share of the money from that is to be distributed among the monks. And that which is not able to be so realized is to be deposited in the storehouse as property in common for the Community of Monks from the Four Directions. ${ }^{60}$

Now the question arises: Can our Gandhāran collections be regarded as parts of such a koșthikāe The description given for the Bajaur Collection (a stone chamber) would at least not contradict this explanation. There is, however, yet another indication. Among the birch-bark scrolls of the Bajaur Collection there is one manuscript which contains exactly this type of written document, which the second Civaravastu passage calls patralekhya - a kind of loan document. The Bajaur fragment 15 uses the closely related term hastalekha. As the address line of the document indicates, it originally belonged to a person named Bhudamitra from Mitrasthāna. ${ }^{61}$ As far as the rather fragmentarily preserved text permits interpretation, the transaction recorded here was a credit business with no direct link with the monastic community. Thus a possible explanation for its being stored in a monastic depository of manuscripts could be based on the passage of the Civaravastu: a layperson bequeathed or donated this loan document to the Buddhist community, which kept it until it could be realised.

In the light of the Civaravastu we could thus consider a third possibility after Salomon's "ritual burial” theory and Schopen's genizah cum scriptorium hypothesis (related to Gilgit): The (or some of the) collections of Gandhāran

58 Thus Dutt and the Tibetan and Chinese translations (cf. below fn. 60). The manuscript reads śakyate ta da dha yi tum, which could be interpreted as an erroneous reading for tad ādhāyitum. The latter word can be possibly connected with Skt. $\bar{a}$ - $d h \bar{a}$ "to deposit". For the infinitive form cf. Buddhist Sanskrit antarahāyitum (Edgerton 1953: 217) and Pāli antaradhāyitum (CPD s.v. antaradhāyati). It is possible that the scribe of the Gilgit manuscript had a corrupt manuscript at his hand and therefore "corrected" the expected sādhayitum resulting in a somewhat odd sentence. 59 Dutt's edition: patralekhyam yac chīghrạ̣ śakyate sādhayitum tasya dravyavibhāge tad bhikṣubhir bhājayitavyam / na śakyate tac cāturdiśāya bhikṣusaṃghāya dhāraṇa / koșṭhikāyāṃ prakșeptavyam / (Dutt 1942: 143, lines 7-9).

60 Translation by Schopen 1995: 500 = 2004: 119. As Schopen (1995: 485 = 2004: 105) rightly remarks, this passage of the Mūlasarvāstivāda Vinaya was the source of the $36^{\text {th }}$ chapter of Yijing's "Record of the Buddhist Religion as Practiced in India and the Malay Archipelago". Yijing's translation says: "If deeds and contracts are payable at once, (the money is) to be realised and to be immediately distributed; if they are not payable at once, the deeds should be kept in the treasury, and when they fall due, (the money) should be devoted to the use of the Assembly." (Takakusu 1998: 192).

61 Strauch 2007/8: 65. 
manuscripts could also be perceived as parts of a monastery's treasury, where according to the Mūlasarvāstivāda Vinaya books, legal documents and money could be deposited.

The preceding discussion does not aim at arguing that Salomon's theory about the ritual burial of Gandhāran manuscripts is wrong. There are indeed serious arguments which are in its favour. But as tempting or convincing these arguments may be, we should keep in mind that we have no positive evidence for their support. Thus the "ritual interment" or "burial” of Gandhāran manuscripts remains a theory - until archaeological or literary evidence can prove it. Based on this evaluation, one should remain open to other explanations.

\section{Gandhāran colophons: places and agents of manuscript production}

But how were these manuscripts produced and used before they were deposited either in a reused water-pot or in a stone chamber, and which were perhaps part of a monastic library, scriptorium or storehouse?

In general our manuscripts are completely silent about this side of their history. As noticed by Schopen, ${ }^{62}$ colophons would be the appropriate place if we want to know who wrote a manuscript, on whose behalf and for what purpose. But unfortunately, such colophons are nearly entirely missing in the case of Gandhāran manuscripts.

A rare exception is the Prajñāpāramitā scroll of the "Split Collection”. The scroll concludes with the statement:

pațhamage postage prañaparamidae budha[mitra] ///

idraśavasa sadhaviharisa imeṇa ca kuśalamuleṇa sarvasatvamatrapi(trap)u(?yae) ///

This is the first book of the Prajñāpāramitā, (of) Buddhamitra [...], the room-companion of Indraśrava. And may it be, through this root of bliss, [...] for the veneration of all living beings, for mother and father. ${ }^{63}$

With regard to the questions raised above, this colophon highlights two points:

1. The text was either written, commissioned or owned (the verb is unfortunately missing) by a Buddhist monk as the term sadhavihari (Pāli saddhivihārika, Sanskrit sārdhamvihārin) indicates.

62 Schopen 2009: 196, fn. 10.

63 Falk and Karashima 2012: 25. 
2. Writing (or commissioning the writing) was expected to yield religious merit (kuśalamūla).

Another rare case of a Gandhāran colophon comes from the British Library Collection. ${ }^{64}$ It reads:

/// .[e] postag. gasa[e] pacaviśadi 2041 saghaśravasa șamaṇasa. ${ }^{65}$

[. . .] book; twenty-five (25) verses; of the monk Sanghaśrava. ${ }^{66}$

Again a verb is missing - so we cannot know who exactly Samghaśrava was either the scribe, the commissioner, the author or even the owner of the text/ manuscript. But again the status of this person is explicitly referred to. He is designated as șamaṇa, a term which in the context of Gandhāran Buddhism is used to signify a Buddhist monk.

According to the preserved fragments, both these colophons were written at the end of the scroll. In both cases the scroll itself is designated as postaga, Skt. pustaka, a term which entered India from its Western, Iranian neighbours probably in the first centuries CE. ${ }^{67}$ As the example of the Split manuscript shows, the term was used to designate the physical unit "scroll, manuscript" rather than the text itself. The scroll named pațhamage postage, "first scroll/manuscript" contained the initial five chapters of the Prajñāpāramitā sūtra. ${ }^{68}$

This term is also used in the third - well-known - colophon, which belongs to the Khotan manuscript of the Dharmapada edited by John Brough (1962). In the case of the Dharmapada the colophon is written in the beginning of the text. ${ }^{69}$

\section{budhavarmasa șamaṇasa \\ budhanadisadhavayarisa \\ ida dharmapadasa postaka \\ dharmaśraveṇa likhida arañi}

This book of the Dharmapada, of the śramaṇa Buddhavarman, pupil of Buddhanandin, has been written by Dharmaśrava in the monastery.

64 Salomon 1999: 40-42.

65 Quoted from Baums 2009: 609-610, see also Lenz 2010: 154.

66 Salomon 1999: 41.

67 See Falk 1993: 305-306, Falk 2010. The radio-carbon dating fixes the calibrated age of the Prajñāpāramitā scroll to 74 CE (Falk 2011: 20). Therefore this colophon might represent one of the earliest attestations of this term in an Indian language.

68 Cf. Falk and Karashima 2012: 25.

69 As pointed out by Stefan Baums at the XV. Congress of the International Association of Buddhist Studies in Vienna, August 2014, Brough's reading dharmuyane in line 4 (1962: 119) has to be corrected to dharmaśravena. For more comments on the implications of this correction see Baums 2014: 203-205. 
Again the persons who are connected with this manuscript belong to the monastic community. The first of them Buddhanandin (G. budhanadi) is explicitly designated as șamana "monk" and sadhavayari, which corresponds to the word sadhavihari of the Prajñāpāramitā colophon. As in the two other colophons his name is given in the genitive case. Since the second person - Dharmaśrava - is clearly indicated as the scribe, Buddhanandin was most probably the person, who owned this manuscript. This evidence can also help to better understand the colophons of the other two Gandhāran texts. In both cases, the genitive most probably indicates the owner of the manuscript scrolls, rather than their scribe.

The evidence of the Khotan Dharmapada colophon adds another important piece of information. Its concluding phrase dharmaśravena likhida arañi seems to indicate the place where the manuscript was produced. Based on his erroneous reading dharmuyaṇe Brough translated "in the Dharmodyāna in the forest". Taking up Brough's alternative translation "in the park (called) 'Garden of Religion'", with dharmodyāna as "the name of the aranya in question", ${ }^{70}$ Salomon translates: "in the Dharmodyāna forest". ${ }^{71}$ But what does this mean? Were Buddhist texts indeed copied by monks living in forests? Is this consequently one further indication for the activities of "forest monks" in Greater Gandhāra?"2

Although the Gāndhārī term araña/raña goes back to Old Indian araṇya, it was often used in Gandhāra in a technical sense meaning "monastery/monastic complex". According to the inscriptional data these monastic complexes comprised vihāras and stūpas. Inscriptions report about their foundation (pratisțhāpana) or about the erection of relics within their precincts. ${ }^{73}$ If we apply this well attested connotation of Gāndhārī araña/raña to the colophon of the Khotan Dharmapada, it becomes obvious that this manuscript was not written in a forest, but in a Buddhist monastery.

To sum up: The evidence of the Gandhāran colophons indicates a clear monastic background for the production of manuscripts. Contrary to what Schopen assumed for the Gilgit manuscripts, there is no evidence for the participation of Buddhist lay followers in this process.

70 Brough 1962: 177.

71 Salomon 1999: 41.

72 For a good summary about the role of this monastic group - especially in the context of early Mahāyāna - see Boucher (2008: 40-63). A concise summary and evaluation of the discussion is provided by Drewes (2010: 57-62).

73 Cf. the discussion in Strauch 2007: 80. 


\section{The inventory of written texts of Gandhāran Buddhist literature}

Beside the testimony of the archaeological context or the colophons, the inventory of a collection can give us an idea about the use of texts within a specific Buddhist environment. In the case of the Gilgit manuscripts, both Fussman and Schopen stressed the importance of protective texts. The popularity of this genre among the manuscripts can indicate the position of protective texts and rites in the Buddhism of Gilgit in the $6^{\text {th }} / 7^{\text {th }} \mathrm{c}$. AD. What can the inventory of Gandhāran collections tell us about the character of the Buddhism practised there and about the role of manuscripts in it?

At present we know the following single manuscripts and collections of Gāndhārī manuscripts: ${ }^{74}$

\begin{tabular}{|c|c|c|c|}
\hline Name & $\begin{array}{l}\text { Manuscripts/ } \\
\text { scribes }\end{array}$ & $\begin{array}{l}\text { Date } \\
\text { (c. CE) }\end{array}$ & Main source of information \\
\hline \multicolumn{4}{|l|}{ Manuscript collections } \\
\hline British Library Collection & $28 / 21$ & 1 & Salomon 1999 \\
\hline Senior Collection & $24 / 1$ & $1-2$ & Salomon 2003, Allon 2007 \\
\hline $\begin{array}{l}\text { Bamiyan fragments of the Schøyen } \\
\text { and other private collections }\end{array}$ & $>50 />50$ & $2-4$ & $\begin{array}{l}\text { Allon \& Salomon } 2000 \text {, } \\
\text { Allon et al. } 2006\end{array}$ \\
\hline $\begin{array}{l}\text { Central Asian fragments (Pelliot } \\
\text { Collection, Oldenburg Collection) }\end{array}$ & $5-8 / 5-8$ & $2-4$ & $\begin{array}{l}\text { Salomon } 1998 \\
\text { Vorob'eva-Desyatovskaya } \\
2006\end{array}$ \\
\hline Bajaur Collection & $19 / 18$ & $1-2$ & $\begin{array}{l}\text { Strauch } 2007 / 8 \text {, } \\
\text { Strauch } 2008\end{array}$ \\
\hline Split Collection & $5 / 5$ & $-1-2$ & Falk 2011 \\
\hline Unpublished private collection & $1+x / 1+x$ & $1-2$ & Allon \& Salomon 2010: 11 \\
\hline \multicolumn{4}{|l|}{ Single manuscripts } \\
\hline Khotan Dharmapada & $1 / 1$ & $1-2$ & Brough 1962 \\
\hline Library of Congress Scroll & $1 / 2$ & $1-2$ & Salomon \& Baums 2007 \\
\hline University of Washington Scroll & $1 / 1$ & $1-2$ & Glass 2004: 141f. \\
\hline
\end{tabular}

74 The following tables are extracted in a slightly modified shape from Falk and Strauch (2014). 
The distribution of genres among the manuscripts can be subsumed in the following survey:

\begin{tabular}{|c|c|c|c|c|c|c|c|c|c|c|}
\hline Mss. collection/single ms. & 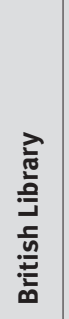 & 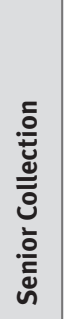 & 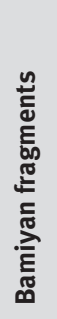 & 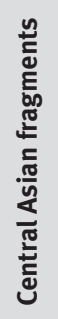 & 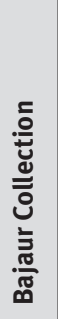 & 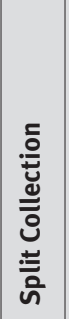 & 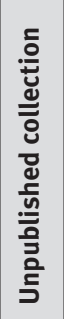 &  & 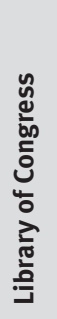 & 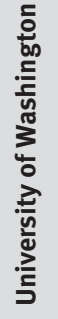 \\
\hline Suggested date (c. CE) & $1-2$ & $1-2$ & $2-4$ & $2-4$ & $1-2$ & $-1-2$ & $1-2$ & $1-2$ & $1-2$ & $1-2$ \\
\hline \multicolumn{11}{|l|}{ Śrāvakayāna Canonical Texts } \\
\hline \multicolumn{11}{|l|}{ Vinaya } \\
\hline \multicolumn{11}{|l|}{ Prātimokșasūtra } \\
\hline \multicolumn{11}{|l|}{ Karmavācanā } \\
\hline \multicolumn{11}{|c|}{ Vinaya related narrative prose } \\
\hline \multicolumn{11}{|l|}{$\bar{A}$ gama sūtra/verse texts } \\
\hline \multicolumn{11}{|l|}{ Dīrghāgama } \\
\hline \multicolumn{11}{|l|}{ Madhyamāgama } \\
\hline \multicolumn{11}{|l|}{ Saṃyuktāgama } \\
\hline \multicolumn{11}{|l|}{ Ekottarikāgama } \\
\hline \multicolumn{11}{|l|}{ Kṣudrakāgama } \\
\hline \multicolumn{11}{|c|}{ Unidentified/unspecified } \\
\hline \multicolumn{11}{|l|}{ Abhidharma (see below) } \\
\hline \multicolumn{11}{|c|}{ Para-canonical (Śrāvakayāna) texts } \\
\hline \multicolumn{11}{|c|}{ Scholastic texts / commentaries } \\
\hline \multicolumn{11}{|l|}{ Scholastic treatises } \\
\hline \multicolumn{11}{|l|}{ Commentaries } \\
\hline \multicolumn{11}{|l|}{ Unspecified texts } \\
\hline \multicolumn{11}{|l|}{ Rakṣā sūtras / Dhāraṇī } \\
\hline \multicolumn{11}{|c|}{ Avadāna / pūrvayoga (collections) } \\
\hline Buddha praises / stotra & & & & & & & & & & \\
\hline
\end{tabular}




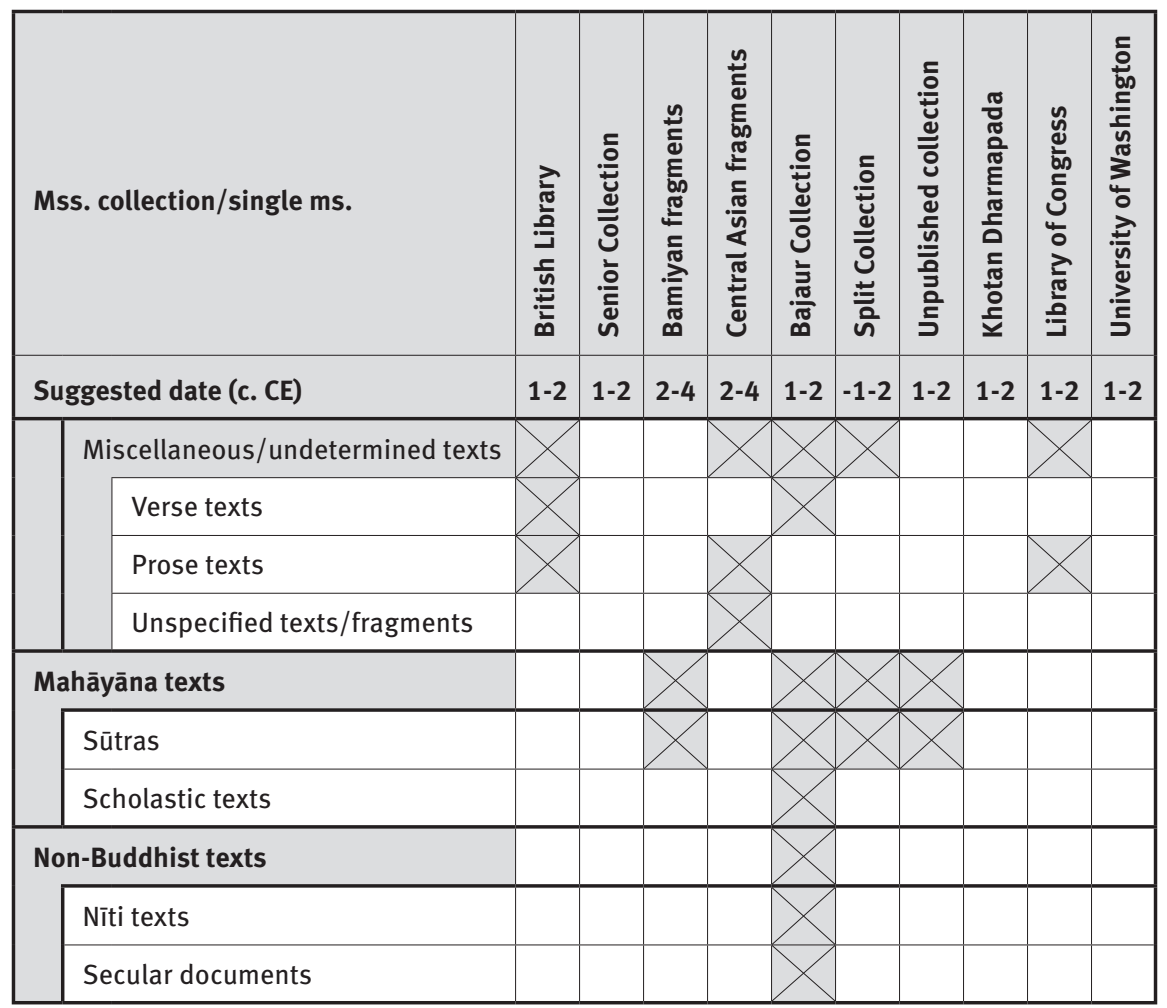

With the exception of the Senior Collection all collections share a rather diverse character and contain texts from a wide range of Buddhist genres, including canonical ägama sūtra texts of early Buddhism, Abhidharma or scholastic texts, paracanonical texts of different types and Mahāyāna sūtras. While all these genres are also represented in the Bajaur Collection, it even contains examples of Vinaya texts and a non-Buddhist text.

This picture is remarkably different from what we know from early Central Asian manuscript culture. The earliest manuscripts, which are datable according to their Kuṣana period script into the second to third centuries CE, belong exclusively to Abhidharma and paracanonical material. ${ }^{75}$ Although these categories are also quite prominently represented in Gāndhārī literature, it seems that the Buddhist culture of this region felt much less hesitation in writing down rather large portions of sūtra literature and even texts from the Vinaya. One explanation for this fact can be seen in the status of the script in the culture of this region. It is

75 Sander 1991 and 1999: 79-83 = 2012: 35-37. 
now widely accepted that the Kharoșthī script is at least slightly older than the second important Indian script, Brāhmī. That it had gained a quite respected status in the region of its use is indicated already by the fact that the King Aśoka decided not to introduce here the newly developed Brāhmī script but to adapt Kharoșthī for the purpose of his edicts. Probably influenced by the important role script played in the neighbouring Iranian culture, Gandhāra seems to have acquired quite early the character of a writing culture. The Buddhists, who came into this region as early as in the 3rd c. BCE, willingly adapted this feature of the Gandhāran culture and started to write down their texts at a comparatively early period of Buddhist history. It is important to note that the act of writing was apparently not confined to any specific genre of Buddhist literature. Instead, the inventory of Gandhāran Buddhist literature seems to reflect a process which embraced all branches of Buddhist literary and intellectual activities. According to the evidence of our collections, specialists in all branches of Buddhist literature - including vinayadhāras, avadānists, and bodhisattvayānikas - participated in this movement. Palaeographical analysis shows that the scribes specialised in particular genres. Usually manuscripts that can be attributed to the same scribe belong to the same genre, e.g. "the avadanist" of the British Library Collection, ${ }^{76}$ or the scribe 5 of the Bajaur Collection, who is responsible for several manuscripts of scholastic texts (BajC 4, 11, 18). ${ }^{77}$

\section{The Bajaur Prātimokșasūtra fragment and the mode of use of manuscripts}

The process of writing down, and the interaction between oral and written modes of textual transmission, were described by Peter Skilling:

\footnotetext{
The relation between writing and Buddhist literature in this period was interactive and dynamic. The movement into a new storage system - from memory to the written word - did not mean that the exercise of memory was abandoned, or even that it was eclipsed - only its functions and contexts changed. Literature - and other arts - flourished, and the use of the written word inspired new possibilities. Any writing down entailed redaction and revision, as texts moved from one storage system to another. ${ }^{78}$
}

Due to the lack of early manuscript material we are usually not very well informed about the mechanisms which characterised this process, and about the specific

76 See Lenz 2010: 6.

77 See Strauch 2007/8: 34-35.

78 Skilling 2009: 72. 
use of manuscripts. Fortunately, some of the Gandhāran manuscripts can help to fill this gap.

Among the Bajaur fragments I could identify the text of a portion of the Buddhist Prātimokșasūtra, the basic text on Buddhist discipline. ${ }^{79}$ This fact alone is of considerable importance, since it had frequently been suggested that texts of this category were committed to writing at a much later period, in the fourth or even fifth century CE. ${ }^{80}$

Much more than any other Buddhist text, the Prātimokșasūtra is connected with oral performance. It had to be recited on every fortnight during the uposatha ceremony by the monastic community. It can be suggested that this text was known by heart to at least a considerable number of monks or nuns. ${ }^{81}$ Therefore it can be expected that this manuscript can provide some evidence for the mechanisms, which accompanied the paradigmatic change from oral to written culture, and for the role of manuscripts in this process.

But there is still another aspect, which is important when discussing this Prātimokșasūtra fragment. It is usually assumed that the identity of a Buddhist community is largely dependent on its reference to a common ordination lineage, which is again based on a common Vinaya including - of course - a common Prātimokșasūtra. Consequently, monks living together within the boundaries of one monastery and belonging to the same Buddhist school (nikāya) should all recite the same text of a clearly identifiable Prātimokṣasūtra.

The Bajaur manuscript, however, seems to contradict this plausible rule: The fragment BajC 13 is a single sheet of birch bark, measuring $16 \mathrm{~cm}$ in width $\times 23 \mathrm{~cm}$ in height. It is inscribed on both sides with two different versions of the beginning of the naihsargika pātayantika section of the Prātimokșasūtra. The letters on the upper right part of the obverse are partially faded, probably due to the contact with some kind of liquid.

The thirty naihsargika pātayantika rules form the fourth section of all extant Prātimokṣasūtras and cover offences, which are related to the monks' property. Their first ten, called in Pāli cīvaravagga, deal with matters concerning the monks' robes. The obverse of the Bajaur manuscript contains the first nine rules, while the reverse remained incomplete due to the lack of space and stopped in the middle of rule 8 . Why the primary text on the obverse contains only nine rules, but not the whole ten, is difficult to explain. But it is possible that the preserved manuscript was originally intended to form part of a larger scroll, which should

79 See Strauch 2007/8: 26-33 and 2008: 116-117.

80 Sander 1991 and 1999: 80-81 = 2012: 36, Salomon 1999: 163-164.

81 That not all of the monks knew this text, was recently shown by Schopen on the basis of passages from the Mūlasarvāstivāda Vinaya (2010). 
contain the entire text of the Prātimokșasūtra including the first three sections that preceded the naihsargika pātayantika rules. Such an intention could be the reason for the rather large space left in the upper portion of the manuscript's recto side (see Figure 1).

It is possible that it was intended for gluing this piece of birch-bark to another one in order to form a larger composite scroll. In any case, this intention - if it ever existed - was quite soon abandoned as shown by the reverse, where the text starts from the very top. Obviously, the piece of birch-bark was now perceived as an independent manuscript.

According to the palaeographical analysis the same scribe wrote both sides. Consequently it can be assumed, that the scribe, who was in the possession of, or responsible for the manuscript, wrote two versions of a Prātimokșasūtra passage, if not at the same time, but certainly within a couple of years.

The versions he used can be characterised with the help of the numerous parallels known for the Prātimokșasūtra from different Buddhist traditions. ${ }^{82}$ According to a comparative analysis conducted on the basis of these parallels, neither of the Gāndhārī versions is identical with any of the known Prātimokṣasūtra texts, be it in Indian languages or in Chinese or Tibetan translations. On the other hand, they can be clearly attributed to different textual traditions: While the text on the obverse is more closely related to the Theravāda and Dharmaguptaka/ Kāśyapiya versions, the text on the reverse can be associated with the Prātimokṣasūtras of the Sarvāstivādins and Mūlasarvāstivādins.

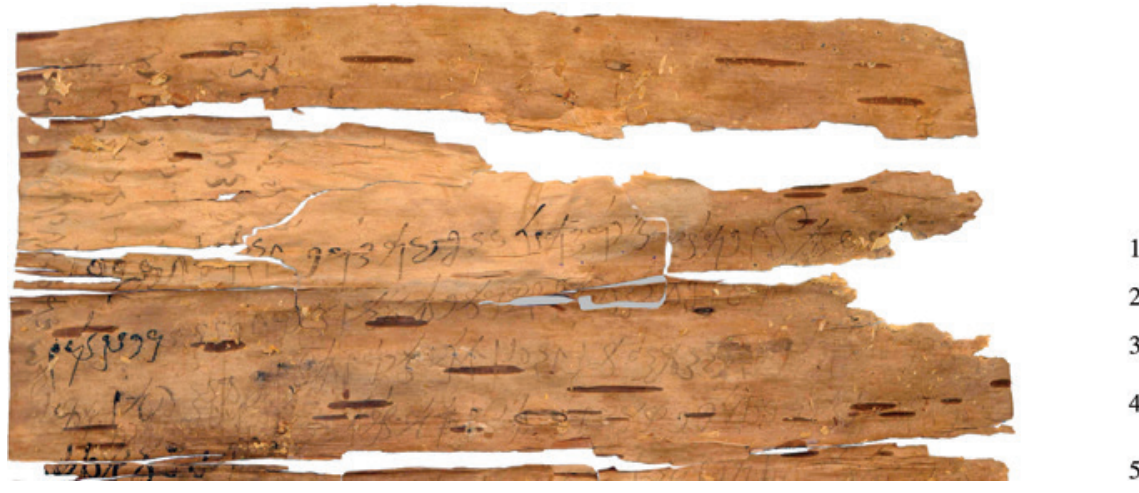

Fig. 1: Upper portion of the manuscript BajC 1 with empty space at the top.

82 Most of these parallels are indicated in the survey made by Akira Yuyama (1979), which was supplemented by Oberlies (2003) and Yamagiwa (2007). For a synoptic treatment of the rules in their different versions see also Pachow 2000: 91-97. 
What is the significance of this evidence for the integrity of texts - even of those of a canonical character - and the significance of textual versions in the process of writing them down?

Of course, we could suppose that our Gāndhārī manuscript contains the Prātimokșasūtras of other, perhaps even unknown schools. But due to the fact that the overwhelming majority of nikāyas, which are attested in Gandhāran epigraphy, are identified with one of the well-known groups, i.e. Mahāsāṃghika, Dharmaguptaka, Sarvāstivāda and Kāśyapīya, it seems more plausible to suggest that our texts should belong to one of them. If this can be accepted, we have to conclude: In the period of the writing down of our manuscripts the Prātimokșasūtras of the Buddhist schools have not yet reached the shape which they feature in the later authoritative text compilations. Consequently, even the formation of the Prātimokṣasūtra texts was not completed in the first or even second centuries CE, but seems to have undergone substantial changes in the process of writing down.

If this was indeed the fact, one might suspect that mainly the writing down of these texts paved the ground for a harmonised and coherent Prātimokșasūtra text tradition within one school. The technique of writing and its opportunities of text preservation and distribution probably directly influenced the emergence of authoritative and codified texts, which were acknowledged and used by communities on a supra-regional level.

According to this hypothesis the Gāndhārī manuscript allows a view into the workshop of one of the proponents of this harmonising process. It seems therefore worthwhile to have a closer look at the formal aspects of this manuscript and its two texts.

The first observation concerns the orthographical features of both versions. Although they are written by the same scribe, they show few, but distinctive differences in their orthographical usages: ${ }^{83}$

\begin{tabular}{|c|c|c|c|}
\hline BajC 13 recto & BajC 13 verso & Sanskrit & Pāli \\
\hline aride[ga] & arideka & atireka & atireka \\
\hline ṇistida & ṇițhida & nișțhita & nitțhita \\
\hline paạ́ighiṇita & pradigiṇidave & pratigrhītavyam & pațiggahetabbam \\
\hline parighiṇ<e>a & pradigh[inea] & pratigrhṇīyād & pațigaṇheyya \\
\hline taśida & tatrida & tatrā $(y a) m$ & tatthāyam \\
\hline
\end{tabular}

83 For comparison columns 3 and 4 cite the Sanskrit and Pāli forms as attested in the parallel texts of the Sarvāstivāda and Theravāda Prātimokșasūtras (ed. von Simson 2000: 184-188, ed. Pruitt and Norman 2001: 28). 
These examples clearly show that both versions follow different orthographical conventions and represent phonologically distinct versions. Of special significance is the pair tasida : tatrida. While the latter variant reflects the usual phonological realisation of Old Indian tr in Gāndhārī, the first variant seems to presuppose a Middle Indian form tatthida (<Skt. *tatredam) which is typical for most of the Indian Prakrits except Gāndhārī. An underlying tatthida written according to the prevailing orthographical conventions of the first century CE as tathida was obviously erroneously interpreted by the author of this version as tathā-idam and "Gāndhārised" to tassida with the usual spirantisation of medial th. In this case we would have to suggest that the Gāndhārī version A preserved a clear trace of the translational process from an original in a different Middle Indian dialect.

The orthographical and phonological differences listed here might support the suggestion that both versions of the Bajaur manuscript represent distinct regional or local varieties of the Prātimokșasūtra current in "Greater Gandhāra". They were copied by the scribe in exactly the same form as he listened or - more probably - read them, without showing any effort to harmonise them in the process of redaction.

Moreover, there is another interesting feature in the Bajaur manuscript, which shows, that such an intention was not completely alien to our scribe. As shown in Figure 2, the scribe used the originally empty space of the obverse side to add an additional passage to the text of the third rule.

Without this addition the rule reads:

3 [...] ṇistidacivareṇa bhikhuṇa ubhadasa kaḍhiṇa

4 bhikhusa a[ga]lacivara upajea agakșamaṇabhikhuṇa paḍ̂ighinita sa[yi parivu]radi kșipram $=e[v a]$

5 kritva dharidave [n]]oya parivura mașaparam[e] bhikhuṇa ta civare ṇikșividave aparivurasa parivurie

6 (sa)[ta](e) [civa]rapracaśa<e $>$ tadutvari ṇikșivea aparivurasa parivurie sata<e $>v a$ civarapracaśae

$7 / / /(3)$

When the kathina frame is taken up by the monk whose robe material is used up, (cloth for) a robe out of season may accrue to a monk. The desirous monk, having taken it, may keep it, after having quickly made (a robe out of it), if it is complete. If it is not complete, the monk may deposit this robe (cloth) for at most one month (with the aim) to make the incomplete complete, there being expectation (to get a complete) robe. If he would deposit it for longer than that (with the aim) to make the incomplete complete, even there being expectation (to get a complete) robe, (it is a naihsargika pāyatti offence). 


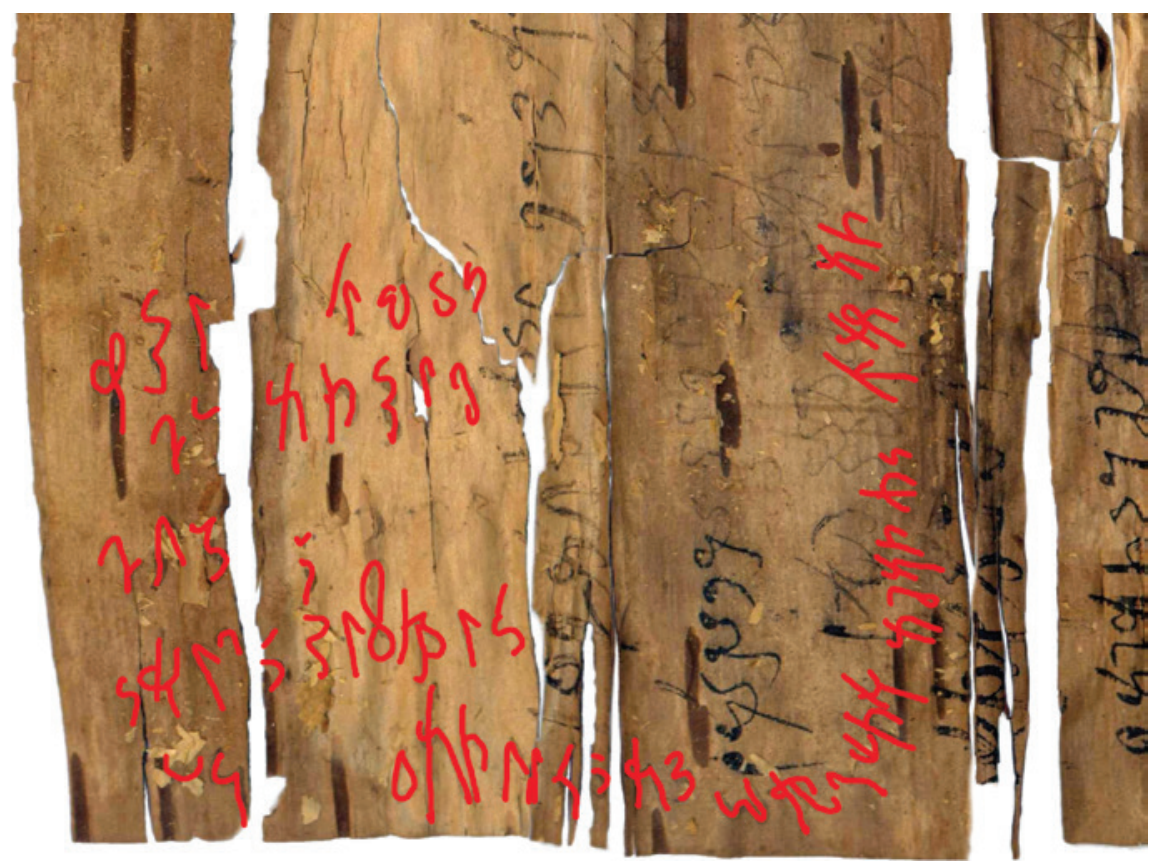

Fig. 2: Detail of the obverse of BajC 1 with inserted text highlighted.

As expected for the version on the obverse, the text of this rule basically corresponds to the text of the Theravāda Prātimokșasūtra

nițțitacīvarasmị̣ bhikkhunā ubbhatasmị̣ kațhine bhikkhuno pan'eva akālacīvaraṃ uppaijeyya, ākan்khamānena bhikkhunā pațiggahetabbaṃ, pātiggahetvā khippameva kāretabbaṃ. noc'assa pāripūri, māsaparamaṃ tena bhikkhunā tạ̣ cīvaram nikkhipitabbaṃ unassa pāripūriyā satiyā paccāsāya, tato ce uttariṃ nikkhipeyya satiyā pi paccāsāya, nissaggiyam pācittiyam ${ }^{84}$

The robe material having been used up, the kathina frame having been removed by a bhikkhu, should out-of-season robe material accrue to a bhikkhu, it is to be accepted by the bhikkhu if he wishes. Having accepted it, it is to be made up quickly. But should it not be sufficient ${ }^{85}$ for him, that robe material is to be deposited by that bhikkhu for a month at most, there being expectation that the deficiency may be supplied. If he should deposit it for longer than that, even with there being expectation, there is an offence entailing expiation with forfeiture. ${ }^{86}$

84 Vin III 203, 32-38, ed. Pruitt and Norman 2001: 28.

85 Thus Pruitt and Norman for pāripūri "fulfilment, accomplishment”, rendered in the Gāndhārī versions as parivuri/parivura.

86 Translation by Pruitt and Norman 2001: 29. 
To this text the scribe added after the word padighinita the following passage. The faded and partially even abraded letters allow only a tentative reconstruction:

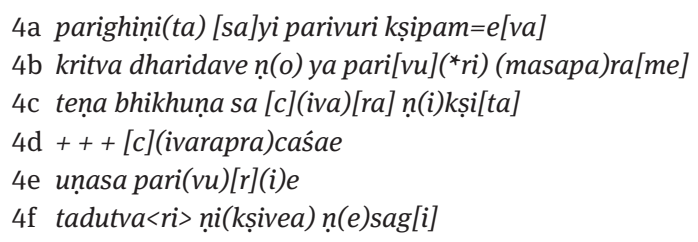

Having taken it, if it is complete, (he) may keep it, after having quickly made (a robe out of it). If it is not complete the monk (may) deposit it for at most one month (...) there being expectation (to get a complete) robe (and with the aim) to make the deficient complete. If he would deposit it for longer than that, it is a naihsargika (pāyatti offence).

Why this insertion was necessary can easily be seen on the reverse. Here the scribe obviously committed a typical haplographic mistake when copying the text and omitted the text between two identical words. The resulting version on the reverse side reads:

5 ṇi[țh]idacivareṇa bhikhuṇa ubhadasa kaḍhina bhi[khusa] (a)[galaci](va)[ra] (*uvajea)

6 agakșamaṇabhikhuṇa pradiginidave sayi parivuryea mașaparame tena bhikhuṇa

7 sa civare ṇikșividave tadutvari ṇikșivea ṇesagipa [ya](ti) [ $\left.{ }^{\circ} 111\right]$

When the kathina frame is taken up by the monk whose robe material is used up, (cloth for) a robe out of season ( ${ }^{\star}$ may accrue) to a monk. The desirous monk may accept (it). If it should be complete, the monk may deposit the robe for at most one month. If he would deposit it for longer than that, it is a naihsargika pāyatti (offence).

It can easily be recognised that in this form the rule is corrupt. Obviously, the scribe erroneously "jumped" from one parivuryea to the next and skipped the text in between. Due to this mistake the sense of the rule, according to which the cloth can only be kept if it does not suffice to prepare a robe, is completely corrupted and turned to its opposite.

According to the Sarvāstivāda version, which is most closely related to the text of the reverse, the correct wording of the rule would be (the missing portion of the Gāndhārī text indicated here by non-italics):

nișthitacīvarasya bhikṣor uddhṛte kațhine utpadyetākālacīvaram āk(ā)ṃkșamāṇena tena bhikșuṇa pratignhìtavyam pratig̣nya sacet paripūryeta kṣipram eva kṛ(tvā) dhārayitavyaṃ no cet paripūryeta māsaparamaṃ tena bhikșuṇā tac civvaram upanikṣi(ptavyaṃ) satyā(ṃ) cìvarapratyāśāyām ūnasya vā paripūryartham tata uttaram upanikșipen niḥsargikā pātaya(n)tikä ${ }^{87}$

87 Ed. von Simson 2000: 184-185. 


\begin{abstract}
Wenn ein Mönch, der seine Gewänder fertig hat, nach Aufhebung der Kațhina-Zeremonie außer der Zeit Stoff für ein Gewand erhält, dann darf er ihn, wenn er will, annehmen. Wenn er ihn angenommen hat und er ausreicht, dann soll er ihn unverzüglich verarbeiten und darf ihn behalten. Wenn er aber nicht ausreicht, dann soll dieser Mönch den Gewandstoff für höchstens einen Monat aufbewahren, wenn erwartet werden kann, dass (daraus) ein Gewand (wird) oder um das Fehlende zu ergänzen. Wenn er ihn länger aufbewahrt, ist es ein Niḥsargikā-Pātayantikā-Vergehen. ${ }^{88}$
\end{abstract}

Probably, while checking the results of his work, the scribe noticed this blunder. But instead of inserting the missing text where it was missing, he inserted it into the parallel rule on the obverse, probably mainly due to the fact that there was sufficient space on the top of the manuscript. As indicated by the abbreviated shape of the concluding phrase of the rule, the text, which the scribe inserted there, is closely related to that of the Sarvāstivāda version:

\title{
Version A
}

Gāndhārī version A (obverse): tadutvari ṇikṣivea aparivurasa parivurie sata<e> va civarapracaśae ///

Pāli version: $\quad$ tato ce uttariṃ nikkhipeyya satiyā pi paccāsāya, nissaggiyam pācittiyam

\section{Version B}

Inserted Gāndhārī text: $\quad$ tadutva<ri $\quad$ nii $(k \operatorname{sivea})$ ṇ(e)sag[i]

Gāndhārī version B (reverse): tadutvari ṇikṣivea ṇesagipa[ya](ti)

Sarvāstivāda version: $\quad$ tata uttaram upanikșipen niḥsargikā pātaya(n)tikā

Thus it is highly probable, that the text inserted on the obverse indeed represents the corrected text of version $B$ of the reverse which is usually very close to the text of the standard Sarvāstivāda Prātimokṣasūtra.

But what does this mean for the status of both versions and for the way, how the Gāndhārī scribe worked with them:

1. It is obvious that the scribe conducted a comparative analysis of both versions and noticed completely correctly which part of version A corresponds to version $\mathrm{B}$.

2. With inserting the missing text of version $B$ into the text of version $A$, the scribe manifested that he had no hesitation to produce a conflated version on the recto. Does this mean, that the Prātimokṣasūtra on the recto had become obsolete and had been replaced by the more modern version B? And if this is

88 Translation by von Simson 2000: 282. 
this case: Does this also mean that the monastic community had changed its school affiliation?

Both these questions cannot be answered on the basis of the available evidence. But the Prātimokșasūtra fragment of the Bajaur Collection demonstrates how writing opened new possibilities for textual development on the basis of the conscious comparison of different text versions. In many cases these developments were probably caused by textual corruptions, which occurred in the process of writing.

The Bajaur Prātimokṣasūtra fragment obviously represents an intermediate state in the development of codified canonical texts - a state when a living oral tradition, which was rooted in a distinct local or probably regional context, was confronted with a growing production of written texts, which somehow petrified these local versions and distributed them into different contexts. The process of harmonisation had of course to take place between the oral versions and the written texts and between the different written texts themselves. Only such a process could eventually result in the emergence of generally accepted and supraregionally used canons with a codified and authoritative textual shape.

\section{Summary}

The manuscripts of Buddhist Gandhāra were produced in a monastic context. From the very beginning the process of writing down involved texts from a variety of Buddhist genres - including canonical texts of the Sūtra and Vinaya literature.

The preserved collections of manuscripts vary according to their character. Some of them (e.g. the Senior Collection) were most probably intentionally prepared in order to be deposited inside a stūpa as representatives of the Buddha's relics. Others can be more properly characterised as remains of monastic libraries, scriptoriums or storehouses (Bajaur Collection, British Library Collection). It is possible, that they consisted of manuscripts, which were sorted out after a certain period of use for different reasons and subsequently deposited in a kind of Buddhist genizah or perhaps even inside a stūpa.

Traces of the period preceding this final deposition allow a cautious view into the working mode of a scriptorium of a Gandhāran Buddhist monastery. It is obvious that texts were not only copied there - from a written or oral template. Different written versions of a text could also undergo a kind of comparative analysis - a process by which differences between them were noticed and new versions could emerge. 


\section{Bibliography}

Allon, Mark (2007): “The Senior Manuscripts”. In: Andrew Glass. Four Gāndhārī Saṃyuktāgama Sūtras: Senior Kharoșțī Fragment 5. (Gandhāran Buddhist Texts; 4). Seattle: University of Washington Press, 3-25.

Allon, Mark / Salomon, Richard (2000): "Kharoșțī Fragments of a Gāndhārī Version of the Mahāparinirvāṇasūtra”. In: Buddhist Manuscripts, Volume I. Edited by Jens Braarvig. (Manuscripts in the Schøyen Collection; 1). Oslo: Hermes Academic Publishing, 243-273. Allon, Mark / Salomon, Richard (2010): "New Evidence for Mahayana in Early Gandhāra”. The Eastern Buddhist 41: 1-22.

Allon, M. / Salomon, R. / Jacobsen, G. / Zoppi, U. (2006): "Radiocarbon Dating of Kharoșțī Fragments from the Schøyen and Senior Manuscript Collections”. In: Buddhist Manuscripts, Volume III. Edited by Jens Braarvig (Manuscripts in the Schøyen Collection; 1). Oslo: Hermes Academic Publishing, 279-291.

Barthoux, Jules (1933): Les fouilles de Hadda. Volume 1: Stupas et sites. Textes et dessins. (Mémoires de la Délégation archéologique française en Afghanistan). Paris: Les éditions d'art et d'histoire.

Baums, Stefan (2009): A Gāndhārī Commentary on Early Buddhist Verses: British Library Kharoșthī Fragments 7, 9, 13 and 18. PhD Dissertation. Seattle: University of Washington.

Baums, Stefan (2014): “Gandhāran scrolls: rediscovering an ancient manuscript type”. In: Manuscript Cultures: Mapping the Field. Edited by Jörg Quenzer and Jan-Ulrich Sobisch (Studies in Manuscript Cultures; 1). Berlin: Walter de Gruyter, 181-224.

Bongard-Levin, G.M. / Vorob’eva-Desyatovskaya, M. I. / Temkin, E.N. (2004): Pamyatniki indiyskoy pis'mennosti iz Tsentral'noy Azii. Vypusk 3 (Pamyatniki Pis'mennosti Vostoka; LXXIII, 3 = Bibliotheca Buddhica; XL). Moskva: Izdatel'skaya Firma "Vostochnaya Literatura".

Boucher, Daniel (2008): Bodhisattvas of the Forest and the Formation of the Mahāyāna: A Study and Translation of the Rāștrapālapariprcchā-sūtra. (Studies in the Buddhist Traditions). Honolulu: University of Hawai'i Press.

Brough, John (1962): The Gāndhārī Dharmapada. (London Oriental Series; 7). London: Oxford University Press.

Chanda, Rāmaprasād (1921): “The Jauliān Manuscript”. In: Marshall, John: Excavations at Taxila. The Stupas and Monasteries at Jauliāñ. (Memoirs of the Archaeological Survey of India; 7). Calcutta: Superintendent Government Printing, 66-75.

CPD. Critical Pāli Dictionary. http://pali.hum.ku.dk/cpd/. (20/05/2014).

Drewes, David (2007): “Revisiting the phrase 'sa prthivīpradeśaś caityabhūto bhavet' and the Mahāyāna cult of the book”. Indo-Iranian Journal 50: 101-143.

Drewes, David (2010): “Early Indian Mahāyāna Buddhism I: Recent Scholarship”. Religion Compass 4.2: 55-65. (http://onlinelibrary.wiley.com/journal/10.1111/(ISSN)1749-8171/ issues?year=2010, last access 20/05/2014).

Dutt, Nalinaksha (ed.) (1942): Gilgit Manuscripts. Volume III. Part 2. Srinagar.

Edgerton, Franklin (1953): Buddhist Hybrid Sanskrit. Grammar and Dictionary. Volume 1: Grammar. New Haven: Yale University Press.

Falk, Harry (1993): Schrift im alten Indien: ein Forschungsbericht mit Anmerkungen. (ScriptOralia; 56). Tübingen: Gunter Narr Verlag. 
Falk, Harry (2010): “Foreign Terms in Sanskrit Pertaining to Writing”. In The Idea of Writing: Play and Complexity. Edited by Alex de Voogt and Irving Finkel. Leiden: Brill, 207-217.

Falk, Harry (2011): “The 'Split' Collection of Kharoșțhī Texts”. Annual Report of the International International Research for Advanced Buddhology, Soka University 14: 13-23.

Falk, Harry / Karashima, Seishi (2012): "A First-Century Prajñāpāramitā Manuscript from Gandhāra - parivarta 1 (Texts from the Split Collection; 1)". Annual Report of the International International Research for Advanced Buddhology, Soka University 15: 19-61.

Falk, Harry / Strauch, Ingo (2014): "The Bajaur and Split Collections of Kharoșțī Manuscripts within the Context of Buddhist Gāndhārī Literature.” In: From Birch-Bark to Digital Data: Recent Advances in Buddhist Manuscript Research: Papers Presented at the Conference 'Indic Buddhist Manuscripts: The State of the Field,'Stanford, June 15-19 2009. Edited by Paul Harrison and Jens-Uwe Hartmann. (Österreichische Akademie der Wissenschaften, philosophisch-historische Klasse, Denkschriften, 460. Band / Beiträge zur Kultur- und Geistesgeschichte Asiens; 80). Wien: Verlag der Österreichischen Akademie der Wissenschaften, $51-78$.

Fussman, Gérard (2004): “Dans quel type de bâtiment furent trouvés les manuscrits de Gilgit?”. Journal asiatique 292: 101-150.

Fussman, Gérard (2012): Review of Andrew Glass (2007). Four Gāndhārī Saṃyuktāgama Sūtras: Senior Kharoșţhī Fragment 5. (Gandhāran Buddhist Texts; 4). Seattle: University of Washington Press. Indo-Iranian Journal 55: 189-200.

Glass, Andrew (2004): “Kharoșțī Manuscripts: A Window on Gandhāran Buddhism”. Nagoya Studies in Indian Culture and Buddhism: Saṃbhāșā 24: 129-152.

Hartmann, Jens-Uwe (2009) "From Words to Books: Indian Buddhist Manuscripts in the First Millenium CE". In: Buddhist Manuscript Cultures: Knowledge, Ritual, and Art. Edited by Stephen C. Berkwitz, Juliane Schober and Claudia Brown. (Routledge critical studies in Buddhism). London: Routledge, 95-105.

Jäschke, H. (1881): A Tibetan-English Dictionary. London (reprint Delhi 1995).

Konow, Sten (1929): Kharoshțhi Inscriptions with the Exception of Those of Aśoka. (Corpus Inscriptionum Indicarum; Vol. II, Part I). Calcutta: Government of India Central Publication Branch.

Konow, Sten (1935/36): “Hidda Inscription of the Year 28”. Epigraphia Indica 23: 35-42. Koshelenko, G.A. (1966): Unikal'naya vaza iz Merva. Vestnik Drevney Istorii 1966.1: 92-105.

Lenz, Timothy (2010): Gandhāran Avadānas: British Library Kharoșțī Fragments 1-3 and 21 and Supplementary Fragments A-C. (Gandhāran Buddhist Texts; 6). Seattle: University of Washington Press.

Litvinskiy, B.A (1992): “Buddizm”. In: Vostochnyy Turkestan v drevnosti i rannem srednevekov'e. Moskva: Nauka, 427-508. German translation: Litvinsky, B. A. (1999). Die Geschichte des Buddhismus in Ostturkestan. (Studies in Oriental Religions; 44). Wiesbaden: Harrassowitz Verlag.

Marshall, John (1951): Taxila: An Illustrated Account of Archaeological Excavations Carried out at Taxila under the Orders of the Government of India between the Years 1913 and 1934. Cambridge: University Press.

Oberlies, Thomas (2003): "Ein bibliographischer Überblick über die kanonischen Texte der Śrāvakayāna-Schulen des Buddhismus (ausgenommen der des Mahāvihāra-Theravāda)." Wiener Zeitschrift für die Kunde Südasiens 47: 37-84. 
Pachow, W. (2000): A Comparative Study of the Prätimokșa. On the Basis of its Chinese, Tibetan, Sanskrit and Pāli Versions. (Buddhist Tradition Series; 31). Delhi: Motilal Banarsidass Publishers (revised and enlarged edition, reprint Delhi 2007).

Pruitt, William (ed.) / Norman, Kenneth Roy (tr.) (2001): The Patimokkha (Sacred Books of the Buddhists; 39). Oxford: The Pāli Text Society.

Raghu Vira / Lokesh Chandra (1995): Gilgit Buddhist Manuscripts: revised and enlarged compact facsimile edition. Delhi: Sri Satguru Publications (2nd edition).

Salomon, Richard (1998): "Kharoșțīi Manuscript Fragments in the Pelliot Collection, Bibliothèque nationale de France". Bulletin d'études indiennes 16: 123-60.

Salomon, Richard (1999): Ancient Buddhist Scrolls from Gandhāra: The British Library Kharoșțī Fragments. Seattle: University of Washington Press.

Salomon, Richard (2003): "The Senior Manuscripts: Another Collection of Gandhāran Buddhist Scrolls". Journal of the American Oriental Society 123: 73-92.

Salomon, Richard (2008): "Whatever happened to Kharoșțhī? The fate of a forgotten Indic script”. In: The Disappearance of Writing Systems: Perspectives on Literacy and Communication. Edited by John Baines, John Bennet and Stephen Houston. London: Equinox Publishing, 139-155.

Salomon, Richard (2009): “Why Did the Gandhāran Buddhists Bury Their Manuscripts?". In: Buddhist Manuscript Cultures: Knowledge, Ritual, and Art. Edited by Stephen C. Berkwitz, Juliane Schober and Claudia Brown (Routledge Critical Studies in Buddhism). London: Routledge, 19-34.

Salomon, Richard (2012): “Gandharan Reliquary Inscriptions”. In: Gandharan Buddhist Reliquaries. Edited by David Jongeward, Elizabeth Errington, Richard Salomon and Stefan Baums (Gandharan Studies; 1). Seattle: Early Buddhist Manuscripts Project, 164-199.

Salomon, Richard / Baums, Stefan (2007): "Sanskrit Ikșvāku, Pali Okkāka, and Gāndhārī Ișmaho”. Journal of the Pali Text Society 29: 201-227.

Sander, Lore (1968): Paläographisches zu den Sanskrit-Handschriften der Berliner Turfansammlung. (Verzeichnis der Orientalischen Handschriften in Deutschland; Supplementband 8). Wiesbaden: Franz Steiner Verlag.

Sander, Lore (1991): “The Earliest Manuscripts from Central Asia and the Sarvāstivāda Mission”. In: Corolla Iranica: Papers in Honour of Prof. Dr. David Neil MacKenzie on the Occasion of His 65th Birthday on April 8th, 1991. Edited by Ronald E. Emmerick and Dieter Weber. Frankfurt am Main: Peter Lang, 133-150.

Sander, Lore (1999): "Early Prakrit and Sanskrit Manuscripts from Xinjiang (Second to Fifth / Sixth Centuries C. E.): Paleography, Literary Evidence, and Their Relation to Buddhist Schools". In: Collection of Essays 1993: Buddhism across Boundaries: Chinese Buddhism and the Western Regions. Edited by Jan Nattier and John R. McRae. Sanchung: Fo Guang Shan Foundation for Buddhist \& Culture Education, 61-106.

Sander, Lore (2012): “Early Prakrit and Sanskrit Manuscripts from Xinjiang (Second to Fifth/ Sixth Centuries C.E.): Paleography, Literary Evidence, and Their Relation to Buddhist Schools". Buddhism Across Boundaries; The Interplay of Indian, Chinese, and Central Asian Source Materials. Edited by John R. McRae and Jan Nattier. (Sino-Platonic Papers; 222). Philadelphia: University of Pennsylvania, 26-49.

Schopen, Gregory (1985): “Two Problems in the History of Indian Buddhism: The Layman/Monk Distinction and the Doctrines of the Transference of Merit". Studien zur Indologie und Iranistik 10: 9-47. 
Schopen, Gregory (1994): “Doing Business for the Lord: Lending on Interest and Written Loan Contracts in the Mūlasarvāstivāda-vinaya". Journal of the American Oriental Society 114: 527-554 (= Schopen 2004: 45-90).

Schopen, Gregory (1995): “Deaths, Funerals, and the Division of Property in a Monastic Code". In: Buddhism in Practice. Edited by Donald S. Lopez. Princeton, 473-502 (= Schopen 2004: 91-121).

Schopen, Gregory (1997): Bones, Stones, and Buddhist Monks: Collected Papers on the Archaeology, Epigraphy, and Texts of Monastic Buddhism in India. (Studies in the Buddhist Traditions; 2). Honolulu: University of Hawai’i Press.

Schopen, Gregory (2004): Buddhist Monks and Business Matters: Still More Papers on Monastic Buddhism in India. (Studies in the Buddhist Traditions). Honolulu: University of Hawai'i Press.

Schopen, Gregory (2009): "On the Absence of Urtexts and Otiose Ācāryas: Buildings, Books, and Lay Buddhist Ritual at Gilgit”. In: Écrire et transmettre en Inde classique. Edited by Gérard Colas and Gerdi Gerschheimer (Études thématiques; 23). Paris: École française d'Extrême-Orient, 189-219.

Schopen, Gregory (2010): “On Incompetent Monks and Able Urbane Nuns in a Buddhist Monastic Code". Journal of Indian Philosophy 38: 107-31.

von Simson, Georg (2000): Prātimokṣasūtra der Sarvāstivādins. Teil II: Kritische Textausgabe, Übersetzung, Wortindex sowie Nachträge zu Teil l. Göttingen: Vandenhoeck \& Ruprecht.

Skilling, Peter (2009): “Redaction, Recitation, and Writing: Transmission of the Buddha's Teaching in India in the Early Period". In: Buddhist Manuscript Cultures: Knowledge, Ritual, and Art. Edited by Stephen C. Berkwitz, Juliane Schober and Claudia Brown (Routledge Critical Studies in Buddhism). London: Routledge, 53-75.

Staviskiy, B. Ya. (1998): Sud'by buddizma v Sredney Azii: po dannym arkheologii. (Kul'tura narodov Vostoka: materialy i issledovaniya). Moskva: Izdatel'skaya firma Vostochnaya literatura.

Strauch, Ingo (2007): “Two Inscribed Pots from Afghanistan”. Gandhāran Studies 1: 77-88.

Strauch, Ingo (2007/8): The Bajaur collection: A new collection of Kharoșthi Manuscripts. A preliminary catalogue and survey. Online version 1.1 (http://www.geschkult.fu-berlin .de/e/indologie/bajaur/publication/strauch_2008_1_1.pdf, last access 20/05/2014).

Strauch, Ingo (2008): "The Bajaur Collection of Kharoșțī Manuscripts - A Preliminary Survey”. Studien zur Indologie und Iranistik 25: 103-136.

Strauch, Ingo (2011): “The character of the Indian Kharoșțī script and the 'Sanskrit revolution': a writing system between identity and assimilation". In: The Idea of Writing. Writing Across Borders. Edited by Alex de Voogt and Joachim Quack. Leiden: Brill, 131-168.

Takakusu, J. (1998): A Record of the Buddhist Religion as practised in India and the Malaya Archipelago (AD 671-695). New Delhi: Munshiram Manoharlal Publishers.

Tarzi, Zemaryalaï (2005): “La céramique de Haḍḍa : étude préliminaire”. In : Art et archéologie des monastères gréco-bouddhiques du Nord-Ouest de l'Inde et de l'Asie centrale : actes du colloque international du Crpoga (Strasbourg, 17-18 mars 2000). Edited by Zemaryalaï Tarzi and Denyse Vaillancourt (Études d'archéologie et d'histoire ancienne). Paris: De Boccard, 209-317.

Vorob’eva-Desyatovskaya, M.I. (1983): “Pamyatniki pis'mom kkharoshtkhi i brakhmi iz Sovetskoy Sredney Azii”. In: Istoriya i kul'tura Tsentral'noy Azii. Moskva: Izdatel'stvo Nauka, 22-96. 
Vorob'eva-Desyatovskaya, M. I. (2006): “Fragment pis’mom kkharoshtkhi iz kollektsii S. F. Ol'denburga". Pis'mennye pamyatniki Vostoka 4: 145-9.

Wilson, H. H. (1841): Ariana antiqua: A Descriptive Account of the Antiquities and Coins of Afghanistan: With a Memoir on the Buildings Called Topes, by C. Masson, Esq. London: The Honourable the Court of Directors of the East India Company.

Yamagiwa Nobuyuki (2007): "Vinaya Manuscripts: State of the Field". In: Indica et Tibetica: Festschrift für Michael Hahn zum 65. Geburtstag von Freunden und Schülern überreicht. Edited by Konrad Klaus and Jens-Uwe Hartmann (Wiener Studien zur Tibetologie und Buddhismuskunde; 66). Wien: Arbeitskreis für Tibetische und Buddhistische Studien Universität Wien, 607-616 [translation of "Ritsuzō kankei shahon kenkyū no genjō". Journal of Indian and Buddhist Studies (Indogaku bukkyōgaku kenkyū), 52/1 (2003): 333-339).

Yuyama, Akira (1979): Systematische Übersicht über die buddhistische Sanskrit-Literatur. Hrsg. von H. Bechert. Erster Teil: Vinaya-Texte. Wiesbaden: Franz Steiner Verlag. 